\title{
PENGEMBANGAN BUKU PETUNJUK PRAKTIKUM \\ IPA TERPADU SMP BERBASIS HOME MATERIALS UNTUK PEMBENTUKAN KARAKTER PESERTA DIDIK
}

\section{Nanang Rahman, Linda Sekar Utami dan Muhammad Nizar \\ Dosen Universitas Muhammadiyah Mataram}

\begin{abstract}
Abstrak
Tujuan dari penelitian ini adalah sebagai berikut: (1) mengembangkan dan mengetahui kualitas buku petunjuk praktikum IPA terpadu berbasis home materials, (2) mengetahui pengaruh penggunaan buku petunjuk praktikum IPA terpadu berbasis home materials terhadap pembentukan karakter peserta didik. Secara umum peneltian ini melalui 3 tahap utama, yaitu: (1) studi pendahuluan, (2) dan pembuatan dan pengembangan produk, (3) evaluasi. Produk yang dikembangkan telah dilakukan validasi oleh ahli materi dan ahli media, serta penilaian pendidik dan peserta didik. Produk yang dikembangkan juga telah dilakukan uji coba terbatas dan Uji coba lapangan di empat sekolah yang ada di daerah Kabupaten Lombok Barat. Berdasarkan hasil penelitian yang telah dilakukan, maka dapat disimpulkan sebagai berikut: (1) Berdasarkan hasil validasi ahli, penilaian pendidik dan peserta didik dapat disimpulkan bahwa produk buku petunjuk praktikum IPA terpadu berbasis home materials telah layak untuk digunakan. (2) Berdasarkan hasil uji coba terbatas dan lapangan diketahui bahwa produk hasil pengembangan dapat meningkatkan karakter tanggung jawab, kreatif dan teliti.
\end{abstract}

Keywords: Petunjuk Praktikum, Home Materials Dan Karakter Peserta Didik 


\section{PENDAHULUAN}

Beberapa hasil penelitian yang telah dilakukan oleh Sriyono \& Hamid (2003) dan Bambang Sumintono (2010), menunjukkan gejala bahwa kemampuan guru dalam mengelola kegiatan laboratorium masih kurang, dan frekuensi penggunaan laboratorium masih rendah karena keterbatasan alat dan bahan praktikum. Sejalan dengan penelitian tersebut, temuan Kelompok Kerja Tenaga Laboratorium (KKTL) tahun 2012, bahwa pemanfaatan dan pengelolaan laboratorium sebagai sumber belajar yang belum optimal atau tidak digunakan disebabkan oleh berbagai faktor diantaranya yaitu: (1) banyak alat-alat laboratorium dan bahan yang sudah rusak yang belum diadakan kembali; dan (2) tidak cukupnya/terbatasnya alat-alat dan bahan mengakibatkan tidak setiap peserta didik mendapat kesempatan belajar untuk mengadakan eksperimen. Berdasarkan hasil penelitian yang dilakukan oleh M. Isnaini (2014) tentang evaluasi kesiapan guru fisika Se-Kota Mataram provinsi Nusa Tenggara Barat dalam kegiatan laboratorium menyatakan bahwa kompetensi guru dalam melakukan kegiatan laboratoium memiliki kategori cukup baik hanya sebesar $52 \%$ dan sebanyak $36.9 \%$ sarana prasaran laboratorium di Kota Mataram dalam kategori baik, 26.2\% berkategori cukup baik dan $36.9 \%$ dalam kategori kurang. Hal yang sama juga terjadi dengan laboratorium di Kabupaten Lombok Barat.

Berdasarkan data yang diperoleh dari wawancara dengan beberapa guru IPA SMP di Kabupaten Lombok Barat menyatakan bahwa sebagian besar guru masih mengalami masalah untuk melakukan praktikum tentang topik-topik tertentu, tidak semua konsep IPA eksperimentatif dapat diajarkan dengan praktikum karena keterbatasan alat dan bahan yang tersedia. Salah satu kendala yang menghambat kelancaran pelaksanaan praktikum IPA di laboratorium adalah terbatasnya jumlah alat dan bahan yang tersedia. Selain adanya masalah dalam hal ketersediaan alat dan bahan praktikum, masalah lain juga yang ada di sekolah daerah Lombok Barat adalah tidak tersedia buku petunjuk praktikum IPA terpadu. Masalah ini terutama dialami oleh sekolah-sekolah yang berada di daerah terpencil. Berdasarkan 
hasil observasi awal di SMPN Satu Atap Gerung Kabupaten Lombok Barat terlihat bahwa guru IPA tidak memiliki buku petunjuk praktikum IPA terpadu, biasanya guru mencari sendiri percobaan praktikum yang ada di buku pelajaran IPA atau mencari di internet.

Berdasarkan analisis situasi yang telah diuraikan menunjukkan bahwa pengembangan buku petunjuk praktikum IPA terpadu SMP berbasis home materials sangat diperlukan. Pernyataan ini diperkuat oleh keterangan beberapa guru IPA, tenaga laboran dan kepala sekolah di daerah Lombok Barat yang menyatakan bahwa perlu pengembangan petunjuk praktikum dengan menggunakan bahan atau alat alternatif yang ada di sekitar lingkungan rumah yang mudah didapatkan. Pengembangan buku petunjuk praktikum IPA terpadu SMP berbasis home materials diharapkan dapat mengatasi masalah sekolah karena adanya keterbatasan alat dan bahan serta tidak tersedia buku petunjuk praktikum sehingga pada akhirnya dapat meningkatkan efektivitas pembelajaran IPA terpadu di sekolah. Oleh karena itu, dalam penelitian ini, peneliti menfokuskan permasalahan pada tiga aspek yaitu (1) bagaimana mengembangkan buku petunjuk praktikum IPA terpadu SMP berbasis home materials untuk pembentukan karakter peserta didik?, (2) bagaimana kualitas buku petunjuk praktikum IPA terpadu SMP berbasis home materials untuk pembentukan karakter peserta didik?, (3) apakah terdapat pengaruh penggunaan buku petunjuk praktikum IPA terpadu SMP berbasis home materials untuk pembentukan karakter peserta didik?.

\section{KAJIAN TEORI}

\section{Pembelajaran IPA terpadu}

Pembelajaran IPA berkaitan dengan cara mencari tahu tentang alam secara sistematis, sehingga IPA bukan hanya penguasaan kumpulan pengetahuan yang berupa fakta-fakta, konsep-konsep, atau prinsip-prinsip saja tetapi juga merupakan suatu proses penemuan. Pembelajaran sains diharapkan dapat menjadi wahana bagi peserta didik untuk mempelajari diri sendiri dan alam sekitar, serta prospek pengembangan lebih lanjut dalam 
menerapkannya di dalam kehidupan sehari-hari. Proses pembelajarannya menekankan pada pemberian pengalaman langsung untuk mengembangkan kompetensi agar menjelajahi dan memahami alam sekitar secara ilmiah. Pendidikan IPA diarahkan untuk inkuiri dan berbuat sehingga dapat membantu peserta didik untuk memperoleh pemahaman yang lebih mendalam tentang alam sekitar (Depdiknas, 2006: 4).

Merujuk pada pengertian IPA itu, maka dapat disimpulkan bahwa hakikat IPA meliputi empat unsur utama yaitu:

1) sikap: rasa ingin tahu tentang benda, fenomena alam, mahluk hidup, serta hubungan sebab akibat yang menimbulkan masalah baru yang dapat dipecahkan melalui prosedur yang benar; IPA bersifat open ended;

2) proses: prosedur pemecahan masalah melalui metode ilmiah; metode ilmiah meliputi penyusunan hipotesis, perancangan eksperimen atau percobaan, evaluasi, pengukuran, dan penarikan kesimpulan;

3) produk: berupa fakta, prinsip, teori, dan hukum;

4) aplikasi: penerapan metode ilmiah dan konsep IPA dalam kehidupan sehari-hari.

\section{Buku Petunjuk praktikum berbasis home materials}

Berdasarkan SK Permendiknas Nomor: 36/D/0/2001 menjelaskan pengertian petunjuk praktikum adalah pedoman pelaksanaan praktikum yang berisi tata cara persiapan, pelaksanaan, analisis data dan pelaporan. Menurut Purnamasari (2012) pada pembelajaran dengan metode praktikum dibutuhkan suatu petunjuk praktikum. Petunjuk praktikum tersebut bertujuan untuk menuntun peserta didik dalam melakukan praktikum dan membantu guru dalam mencapai tujuan pembelajaran. Petunjuk praktikum disusun dan ditulis oleh sekelompok staf pengajar yang menangani praktikum tersebut dan mengikuti kaidah tulisan ilmiah.

Keunggulan buku petunjuk praktikum ini karena menggunakan alat dan bahan yang ada di sekitar lingkungan kita (home materials). Terdapat banyak sekali perangkat praktikum dengan memanfaatkan bahan alternatif yang ada di sekitar lingkungan rumah sebagai bahan pelengkap (suplemen) dan bahan pengganti (komplemen). Alam atau lingkungan sekitar 
sangat potensial dijadikan sabagai sumber untuk mendapatkan bahan-bahan untuk keperluan pembelajaran (praktikum). Sebagai contoh, untuk keperluan praktikum pengenalan senyawa asambasa bahan dapat memanfaatkan ekstrak buah-buahan, batu kapur, air laut dll. Demikian pula sebagai bahan indikator dapat memanfaaatkan bahan alam seperti berbagai ekstrak kembang, umbi-umbian, daun-daunan, dan lain sebagainya.

\section{Pembentukan karakter peserta didik}

Pendidikan karakter adalah suatu sistem penanaman nilainilai kebaikan kepada warga sekolah untuk mengajarkan kebiasaan cara berpikir dan perilaku yang membantu individu untuk hidup dan bekerja sama sebagai keluarga, masyarakat dan bernegara. Komponen dalam penanaman nilai-nilai kebaikan meliputi komponen pengetahuan, kesadaran atau kemauan dan tindakan untuk melaksanakan nilai-nilai tersebut (Darmiyati Zuchdi, 2010:3). Sedangkan menurut Depdiknas (2010:2), karakter adalah suatu nilai-nilai perilaku manusia yang berhubungan dengan Tuhan Yang Maha Esa, diri sendiri, sesama manusia, dan lingkungan yang berwujud pikiran, sikap, perasaan, perkataan dan perbuatan berdasarkan norma agama, kebudayaan, hukum/konstitusi, adat istiadat dan estetika. Pendidikan karakter adalah suatu sistem penanaman nilai-nilai karakter kepada warga sekolah yang meliputi komponen pengetahuan, kesadaran atau kemauan untuk melaksanakan nilainilai tersebut agar menjadi manusia yang kamil.

\section{METODE PENELITIAN}

\section{Tahapan Penelitian Pengembangan}

Prosedur pengembangan yang digunakan dalam penelitian dan pengembangan ini adalah pengembangan secara prosedural dimana langkah-langkahnya dijelaskan secara kongkrit dan rinci. Buku petunjuk praktikum IPA terpadu SMP berbasis home materials yang dikembangkan hanya terbatas pada materi pokok yang dapat menggunakan alat dan bahan alternatif, oleh sebab itu tidak semua materi IPA terpadu dapat dipraktikumkan dengan menggunakan bahan dan alat alternatif. Prosedur pengembangan 
yang dilakukan mengacu kepada prosedur pengembangan menurut Borg \& Galls.

\section{Uji Coba Produk}

Setelah produk pengembangan buku petunjuk praktikum berbasis home materials divalidasi dan dinyatakan layak oleh ahli materi dan ahli media, maka selanjutnya produk tersebut diujicobakan kepada subjek uji coba (peserta didik). Subjek penelitian untuk uji coba produk yang dikembangkan dalam penelitian ini adalah peserta didik Sekolah Menegah Pertama (SMP) di Kabupaten Lombok Barat. Subjek uji coba 1 (uji coba terbatas) adalah 50 orang peserta didik di dua sekolah yang dipilih secara acak. Subjek uji coba II (uji coba lapangan) adalah peserta didik sebanyak 100 orang di empat SMP di kabupaten Lombok Barat.

\section{Teknik Pengumpulan Data}

Untuk menghasilkan produk yang berkualitas diperlukan teknik pengumpulan data dan instrumen yang mampu menggali data yang diperlukan dalam pengembangan produk buku petunjuk praktikum IPA terpadu SMP berbasis home materials. Instrumen yang digunakan untuk mengumpulkan data pada penelitian ini berupa lembar kuesioner kelayakan produk, lembar observasi dan angket karakter.

\section{Analisis Data}

Data yang diperoleh melalui kegiatan uji coba diklasifikasikan menjadi dua, yakni data kualitatif dan kuantitatif. Data kualitatif yang berupa kritik/masukan dan saran yang dikemukakan oleh ahli media, ahli materi, pendidik dan peserta didik dikumpulkan untuk memperbaiki produk buku petunjuk praktikum. Sedangkan data kuantitatif berupa hasil penilaian produk, hasil observasi dan angket karakter.

\section{HASIL DAN PEMBAHASAN}

\section{Tahap Evaluasi/Penilaian Produk}

Data yang diperoleh dalam penelitian pengembangan buku petunjuk praktikum ini merupakan data hasil validasi yang dilakukan oleh ahli dan data penilaian yang dilakukan oleh 
pendidik serta peserta didik. Data hasil validasi dan penilaian juga dilengkapi dengan masukan serta komentar terhadap produk yang dikembangkan.

Tujuan validasi ahli adalah untuk memberikan nilai dan menentukan kelayakan dari perangkat pembelajaran yang telah dikembangkan. Penilaian yang dilakukan oleh pendidik dan peserta didik adalah untuk mendapatkan nilai terhadap produk yang dikembangkan. Validasi dan penilaian juga bertujuan untuk memperoleh komentar dan saran, baik secara tertulis maupun lisan dengan cara berdiskusi tentang buku petunjuk praktikum IPA terpadu berbasis home materials. Rekap hasil validasi oleh 2 orang ahli dan penilaian oleh 4 orang pendidik.

\section{Tabel 1}

Hasil penilaian ahli dan pendidik Terhadap Buku Petunjuk Praktikum

\begin{tabular}{|l|l|c|c|}
\hline No & \multicolumn{1}{|c|}{ Aspek yang Dinilai } & Ahli & Pendidik \\
\hline 1 & $\begin{array}{l}\text { Penulisan dan organisasi buku petunjuk } \\
\text { praktikum }\end{array}$ & 9,00 & 8,50 \\
\hline 2 & Kebenaran konsep dan materi & 13,00 & 13,50 \\
\hline 3 & Kejelasan kalimat dan tingkat keterbacaan & 9,00 & 8,50 \\
\hline 4 & Tingkat keterlaksanaan kegiatan praktikum & 9,00 & 9,25 \\
\hline 5 & Evaluasi hasil praktikum & 11,00 & 10,00 \\
\hline 6 & Tampilan fisik buku petunjuk praktikum & 9,00 & 9,25 \\
\hline 7 & Aspek karakter & 5,00 & 5,00 \\
\hline
\end{tabular}

Berdasarkan hasil penilaian (Tabel 1) yang dilakukan oleh ahli dan pendidik terhadap produk buku petunjuk praktikum IPA Terpadu berbasis home materials, maka dapat diuraikan sebagai berikut: (1) aspek penulisan dan organisasi buku petunjuk praktikum mendapatkan mendapatkan nilai A sehingga termasuk kategori sangat baik, (2) aspek kebenaran konsep dan materi mendapatkan nilai A sehingga termasuk kategori sangat baik, (3) aspek kejelasan kalimat dan tingkat keterbacaan mendapatkan nilai A sehingga termasuk kategori sangat baik, (4) aspek tingkat keterlaksanaan kegiatan praktikum mendapatkan nilai A sehingga termasuk kategori sangat baik, (5) aspek evaluasi hasil praktikum mendapatkan nilai B sehingga termasuk kategori baik, (6) aspek 
tampilan fisik buku petunjuk praktikum mendapatkan nilai A sehingga termasuk kategori sangat baik, (7) aspek karakter mendapatkan nilai A sehingga termasuk kategori sangat baik. Berdasarkan penilaian ahli dan pendidik terhadap produk buku petunjuk praktikum IPA terpadu berbasis home materials dapat disimpulkan bahwa produk hasil pengembangan dikategorikan sangat baik sehingga layak untuk digunakan.

\section{Hasil Uji Coba Terbatas}

Uji coba terbatas dilakukan di SMPN 1 Labuapi dan SMPN 1 Gerung dengan jumlah subjek uji coba sebanyak 50 orang peserta didik. Pada SMPN 1 Labu api digunakan 25 peserta didik dan 25 lainnya pada SMPN 1 Gerung. Hasil uji coba terbatas yang telah dilakukan mendapatkan 2 data yaitu data tanggapan peserta didik terhadap produk yang telah diujicobakan dan data hasil observasi karakter peserta didik. Uji coba terbatas dilakukan sebanyak 2 kali pertemuan yang dilakukan di laboratorium IPA yang dimiliki oleh sekolah subjek uji coba.

\subsection{Data penilaian peserta didik terhadap produk}

Penilaian produk buku petunjuk praktikum IPA Terpadu berbasis berbasis home materials yang telah dilakukan oleh peserta didik hanya meliputi 5 aspek, yaitu : kejelasan kalimat dan tingkat keterbacaan, tingkat keterlaksanaan kegiatan praktikum, evaluasi hasil praktikum, tampilan fisik buku petunjuk praktikum dan aspek karakter. Data hasil penilaian peserta didik terhadap produk yang telah digunakan sebagai berikut.

Tabel 2

Penilaian peserta didik terhadap produk

\begin{tabular}{|c|l|c|}
\hline No & Aspek yang dinilai & Rerata nilai \\
\hline 1 & $\begin{array}{l}\text { Kejelasan kalimat dan tingkat } \\
\text { keterbacaan }\end{array}$ & 7,25 \\
\hline 2 & $\begin{array}{l}\text { Tingkat keterlaksanaan kegiatan } \\
\text { praktikum }\end{array}$ & 8,15 \\
\hline 3 & Evaluasi hasil praktikum & 10,48 \\
\hline 4 & $\begin{array}{l}\text { Tampilan fisik buku petunjuk } \\
\text { praktikum }\end{array}$ & 9,45 \\
\hline 5 & Aspek karakter & 3,83 \\
\hline
\end{tabular}

182 BIOTA: Jurnal Tadris IPA Biologi FITK IAIN Mataram 
Hasil penilaian oleh peserta didik kemudian dikonversikan menjadi skala 5, berdasarkan tabel konversi (Tabel 2) yang telah dibuat, maka dapat diuraikan sebagai berikut: (1) aspek kejelasan kalimat dan tingkat keterbacaan mendapatkan nilai B sehingga termasuk kategori baik, (2) aspek tingkat keterlaksanaan kegiatan praktikum mendapatkan nilai A sehingga termasuk kategori sangat baik, (3) aspek evaluasi hasil praktikum mendapatkan nilai B sehingga termasuk kategori baik, (4) aspek tampilan fisik buku petunjuk praktikum mendapatkan nilai A sehingga termasuk kategori sangat baik, (5) aspek karakter mendapatkan nilai B sehingga termasuk kategori baik. Berdasarkan penilaian ahli dan pendidik terhadap produk buku petunjuk praktikum IPA terpadu berbasis home materials dapat disimpulkan bahwa produk hasil pengembangan dikategorikan baik sehingga layak untuk digunakan.

\subsection{Data hasil pembentukan karakter}

Pengukuran terhadap pembentukan karakter peserta didik berdasarkan pada data angket dan lembar observasi karakter. Skor aktual yang diperoleh peserta didik merupakan rerata dari kedua pengukuran tersebut. Terdapat 3 karakter yang akan dibentuk dalam penelitian ini, yaitu: tanggung jawab, kreatif, dan teliti. Pada bagian ini akan dijabarkan data hasil pembentukan untuk setiap karakter. 
Tabel 3

Hasil pembentukan karakter Peserta Didik

\begin{tabular}{|c|c|c|c|}
\hline Karakter & Nilai & Kategori & $\begin{array}{c}\text { Jumlah } \\
\text { subjek }\end{array}$ \\
\hline \multirow{4}{*}{ Tanggung jawab } & $\mathrm{A}$ & Sangat baik & 28 \\
\cline { 2 - 4 } & $\mathrm{B}$ & Baik & 14 \\
\cline { 2 - 4 } & $\mathrm{C}$ & Cukup baik & 8 \\
\cline { 2 - 4 } & $\mathrm{D}$ & Kurang baik & - \\
\cline { 2 - 4 } & $\mathrm{E}$ & Sangat kurang baik & - \\
\hline \multirow{7}{*}{ Kreatif } & $\mathrm{A}$ & Sangat baik & 14 \\
\cline { 2 - 4 } & $\mathrm{B}$ & Baik & 27 \\
\cline { 2 - 4 } & $\mathrm{C}$ & Cukup baik & 8 \\
\cline { 2 - 4 } & $\mathrm{D}$ & Kurang baik & 1 \\
\cline { 2 - 4 } & $\mathrm{E}$ & Sangat kurang baik & - \\
\hline \multirow{7}{*}{ Teliti } & $\mathrm{A}$ & Sangat baik & 32 \\
\cline { 2 - 4 } & $\mathrm{B}$ & Baik & 8 \\
\cline { 2 - 4 } & $\mathrm{C}$ & Cukup baik & 10 \\
\cline { 2 - 4 } & $\mathrm{D}$ & Kurang baik & - \\
\cline { 2 - 4 } & $\mathrm{E}$ & Sangat kurang baik & - \\
\hline
\end{tabular}

Berdasarkan tabel 3, maka dapat disimpulkan bahwa pembentukan karakter tanggung jawab termasuk dalam kategori sangat baik, pembentukan karakter kreatif termasuk dalam kategori baik, dan pembentukan karakter teliti termasuk dalam kategori sangat baik.

Untuk menentukan adanya peningkatan pembentukan karakter, dapat dilihat dari data angket yang diberikan sebelum penggunaan produk (pretest) dan setelah penggunaan produk (posttest).Berikut data rerata pembetukan karakter pada uji coba terbatas. 


\section{Tabel 4}

Rerata Pretest dan Postest Pembetukan Karakter Pada Uji Coba Terbatas

\begin{tabular}{|l|c|c|c|}
\hline \multicolumn{1}{|c|}{ Karakter } & Pretest & Postest & Gain standar \\
\hline Tanggung Jawab & 8,15 & 11,21 & 0,44 \\
\hline Kreatif & 5,45 & 7,13 & 0,37 \\
\hline Teliti & 5,13 & 7,31 & 0,45 \\
\hline
\end{tabular}

Berdasarkan Tabel 4, maka dapat disimpulkan bahwa terjadi peningkatan karakter Tanggung jawab, kreatif dan teliti dalam kategori "sedang". Hal ini terjadi karena adanya pengaruh penggunaan buku petunjuk praktikum IPA terpadu berbasis home materials yang merupakan produk hasil pengembangan.

\subsection{Hasil Uji Coba Lapangan}

Uji coba lapangan dilakukan di empat sekolah yang ada di Kabupaten Lombok Barat (SMPN 1 Labuapi, SMPN 1 Gerung, SMPN 2 Gerung dan SMPN satap Gerung) dengan jumlah subjek uji coba sebanyak 100 orang peserta didik. Pada setiap sekolah digunakan 25 peserta didik sebagai subjek uji coba. Hasil uji coba lapangan yang telah dilakukan mendapatkan 2 data yaitu data tanggapan peserta didik terhadap produk yang telah diujicobakan dan data hasil observasi karakter peserta didik. Uji coba lapangan dilakukan sebanyak 4 kali pertemuan yang dilakukan di laboratorium IPA yang dimiliki oleh sekolah subjek uji coba.

\subsection{Data penilaian peserta didik terhadap produk}

Penilaian produk buku petunjuk praktikum IPA Terpadu berbasis berbasis home materials yang telah dilakukan oleh peserta didik hanya meliputi 5 aspek, yaitu: kejelasan kalimat dan tingkat keterbacaan, tingkat keterlaksanaan kegiatan praktikum, evaluasi hasil praktikum, tampilan fisik buku petunjuk praktikum dan aspek karakter. Data hasil penilaian peserta didik terhadap produk yang telah digunakan sebagai berikut: 


\section{Tabel 5}

Penilaian peserta didik terhadap produk

\begin{tabular}{|c|l|c|}
\hline No & \multicolumn{1}{|c|}{ Aspek yang dinilai } & Rerata nilai \\
\hline 1 & Kejelasan kalimat dan tingkat keterbacaan & 7,05 \\
\hline 2 & Tingkat keterlaksanaan kegiatan praktikum & 8,48 \\
\hline 3 & Evaluasi hasil praktikum & 12,32 \\
\hline 4 & Tampilan fisik buku petunjuk praktikum & 9,15 \\
\hline 5 & Aspek karakter & 4,45 \\
\hline
\end{tabular}

Hasil penilaian oleh peserta didik kemudian dikonversikan menjadi skala 5, berdasarkan tabel konversi yang telah dibuat (Tabel 5), maka dapat diuraikan sebagai berikut: (1) aspek kejelasan kalimat dan tingkat keterbacaan mendapatkan nilai B sehingga termasuk kategori baik, (2) aspek tingkat keterlaksanaan kegiatan praktikum mendapatkan nilai A sehingga termasuk kategori sangat baik, (3) aspek evaluasi hasil praktikum mendapatkan nilai A sehingga termasuk kategori sangat baik, (4) aspek tampilan fisik buku petunjuk praktikum mendapatkan nilai A sehingga termasuk kategori sangat baik, (5) aspek karakter mendapatkan nilai A sehingga termasuk kategori baik. Berdasarkan penilaian ahli dan pendidik terhadap produk buku petunjuk praktikum IPA terpadu berbasis home materials dapat disimpulkan bahwa produk hasil pengembangan dikategorikan baik sehingga layak untuk digunakan.

\subsection{Data hasil pembentukan karakter}

Pengukuran terhadap pembentukan karakter peserta didik berdasarkan pada data angket dan lembar observasi karakter. Skor aktual yang diperoleh peserta didik merupakan rerata dari kedua pengukuran tersebut. Terdapat 3 karakter yang akan dibentuk dalam penelitian ini, yaitu: tanggung jawab, kreatif, dan teliti. Pada bagian ini akan dijabarkan data hasil pembentukan untuk setiap karakter. 


\section{Tabel 6}

Hasil pembentukan karakter Peserta Didik

\begin{tabular}{|c|c|c|c|}
\hline Karakter & Nilai & Kategori & $\begin{array}{c}\text { Jumlah } \\
\text { subjek }\end{array}$ \\
\hline \multirow{4}{*}{ Tanggung jawab } & A & Sangat baik & 47 \\
\cline { 2 - 4 } & B & Baik & 32 \\
\cline { 2 - 4 } & C & Cukup baik & 21 \\
\cline { 2 - 4 } & D & Kurang baik & - \\
\hline \multirow{4}{*}{ Kreatif } & E & Sangat kurang baik & - \\
\hline & A & Sangat baik & 52 \\
\cline { 2 - 4 } & B & Baik & 24 \\
\cline { 2 - 4 } & C & Cukup baik & 16 \\
\cline { 2 - 4 } & D & Kurang baik & 8 \\
\hline \multirow{5}{*}{ Teliti } & E & Sangat kurang baik & - \\
\cline { 2 - 4 } & A & Sangat baik & 63 \\
\cline { 2 - 4 } & B & Baik & 17 \\
\cline { 2 - 4 } & C & Cukup baik & 18 \\
\cline { 2 - 4 } & D & Kurang baik & - \\
\hline
\end{tabular}

Berdasarkan table 6, maka dapat disimpulkan bahwa pembentukan karakter tanggung jawab termasuk dalam kategori sangat baik, pembentukan karakter kreatif berkategori sangat baik, dan pembentukan karakter teliti termasuk dalam kategori sangat baik.

Untuk menentukan adanya peningkatan pembentukan karakter, dapat dilihat dari data angket yang diberikan sebelum penggunaan produk (pretest) dan setelah penggunaan produk (posttest). Berikut data rerata pembetukan karakter pada uji coba lapangan.

\section{Tabel 7}

Rerata Pretest dan Postest pembetukan karakter pada uji coba lapangan

\begin{tabular}{|c|c|c|c|}
\hline Karakter & Pretest & Postest & Gain standar \\
\hline Tanggung Jawab & 8,05 & 13,12 & 0,62 \\
\hline Kreatif & 4,45 & 8,43 & 0,67 \\
\hline Teliti & 5,13 & 8,31 & 0,62 \\
\hline
\end{tabular}


Pengaruh penggunaan buku petunjuk praktikum IPA terpadu berbasis home materials yang merupakan produk hasil pengembangan.

\section{KESIMPULAN DAN SARAN}

Berdasarkan hasil penelitian yang telah dilakukan, maka dapat disimpulkan sebagai berikut:

a. Berdasarkan hasil validasi ahli, penilaian pendidik dan peserta didik dapat disimpulkan bahwa produk buku petunjuk praktikum IPA terpadu berbasis home materials telah layak untuk digunakan.

b. Berdasarkan hasil uji coba terbatas dan lapangan diketahui bahwa produk hasil pengembangan dapat meningkatkan karakter tanggung jawab, kreatif dan teliti.

\section{DAFTAR PUSTAKA}

Darmiyati Zuchdi, Zuhdan Kunprasetya, Marzuki, et al. 2010. Pendidikan karakter dengan pendekatan komprehensif. Yogyakarta: UNY Press.

Depdiknas. 2006. Panduan Pengembangan Pembelajaran IPA Terpadu, SMP/MTs.Jakarta: Pusat Kurikulum Balitbang Diknas.

Isnaini, M. 2014. Evaluasi kesiapan guru fisika se-kota mataram dalam kegiatan laboratorium, prosiding: seminar nasional tema" sains dan inovasi pembelajaran berbasis kearifan local. IKIP Mataram.

Sriyono \& A. Hamid. 2003. "Pemanfaatan Laboratorium dalam Pembelajaran Fisika SMU." Makalah dipresentasikan pada Seminar Nasional Pendidikan MIPA yang diselenggarakan oleh FMIPA Unnes pada tanggal 22 Februari 2003. 
Sumintono, B. 2010. "Pengajaran Sains dengan Praktikum Laboratorium: Perspektif dari Guru guru Sains SMPN di Kota Cimahi". Jurnal Penelitian Pendidikan, Vol 15, No. 2. 